THURSDAY, AUGUST I3, I9I4.

AGRICULTURAL BACTERIOLOGY.

Vorlesungen über landwirtschaftliche Bakteriologie. By Dr. F. Löhnis. Pp. viii $+398+x$ plates. (Berlin: Gebrüder Borntraeger, 19r3.) Price 16 marks.

M ODERN research has established the mani1 fold activities exerted by micro-organisms in almost every department of agriculture and the attention of micro-biologists has naturally been directed to a study of the micro-organisms present in soil which influence its fertility, and of those met with in fodder and manure and in agricultural products such as milk, butter, and cheese. The result has been that many books dealing with these subjects have appeared during the last few years, but we doubt if any single volume has been issued which will compare with that under review in the completeness with which agricultural bacteriology is treated in a comparatively short space of five and twenty lectures. Prof. Löhnis has managed to convey an admirable summary of the whole subject.

The volume commences with an excellent historical introduction in which the author directs attention to papers by E. King, published in 1693 , in the Philosophical Transactions of the Royal Society, London (vol. xvii), which seem to have been overlooked and which confirm and extend the observations of Leeuwenhoek on the presence of micro-organisms in various organic fluids. The second and third lectures deal with the general morphology, classification, and nomenclature of the bacteria. The author adopts practically the old Zopf classification, remarking that no better one has yet been formulated; with this we cordially agree. Succeeding lectures deal with the biology, cultivation, and investigation of microorganisms, the circulation in nature of nitrogen, carbon, hydrogen, and oxygen, exchange and decomposition of mineral salts, and the pathogenic functions of micro-organisms, and this completes the first part of the volume. The second part deals with micro-organisms present in fodder, milk and milk products, manure and soil, and the changes which they produce. In this we find accounts of the cellular elements in milk, the heating of manure and hay, nitrification, the possible influence of protozoa and of "toxins" in the soil on fertility, and the use of artificial bacterial fertilisers. In the last connection we miss any reference to Prof. Bottomley's investigations.

The volume is excellently printed and produced, and the illustrations form a striking feature. There are ten plates, of which eight are coloured No. 2337, VOL. 93] and admirably depict the objects represented, one of the most successful perhaps being that of a sole glowing with phosphorescent bacteria, a most difficult subject to reproduce. There are sixty figures in the text, some of which are novel. By depicting a rectangular jar of given size with a small black square in it drawn to scale an idea is given of the volume occupied by a certain number of bacteria compared with the volume of the material in which they occur, such, for example, as milk.

R. T. H.

\section{THE CONSTITUTION OF ALLOYS.}

Metallographie. By Dr. W. Guertler. Erster Band: Die Konstitution. Erster Teil. Heft i.-xii. Pp. II77. (I909-rgi2. Zweiter Teil.) Heft. i., Die Konstitution des Systemes EisenKohlenstoff sowie der sonstigen binären Kohlenstofflegierungen. Pp. $\mathrm{xl}+648+$ plates. (Berlin: Gebrüder Borntraeger, 1913.) Price 32 marks.

THE scientific study of alloys has attracted a whole host of investigators during the last twelve years, and the mass of experimental material has increased with great. rapidity. Metallography has become a distinct branch of applied physical chemistry, having numerous contacts with mineralogy and with engineering science. There are many text-books dealing with the principles of metallography or with its applications, but the work now in course of publication by Dr. Guertler has a much wider scope. It aims at being a complete treatise on the subject, reviewing critically both methods and results, and also serving as a work of reference. The practical methods of thermal analysis, micrographic examination, etc., and the physical properties of alloys, are left for discussion in later volumes, and the volumes now published deal only with the equilibrium of phases in alloys. The general explanation of the meaning of the equilibrium diagram has been written with the object of making such diagrams intelligible and useful to the technical metallurgist, who may not be acquainted with the principles of physical chemistry. This general account is very clearly written, but the number of new terms introduced, and the rather complicated illustrations of possible forms of equilibrium, may repel some such readers. The discussions of such subjects as diffusion and incomplete equilibrium are excellent.

Just one-half of the first of the present volumes is occupied by a detailed account of binary alloys, classified according to a modified periodic system. Even then, the alloys of the calcium and aluminium groups are postponed to a later section, B B 